\title{
The Passive Transfer of Immediate Type Hypersensitivity from Man to Other Primates *
}

\author{
Roy Patterson, $\dagger$ Jordan N. Fink, Edwin T. Nishimura, $\ddagger$ and \\ Jacob J. Pruzansky \\ (From the Allergy Unit, Department of Medicine, and the Department of Pathology, \\ Northwestern University Medical School, Chicago, Ill.)
}

There have been various obstacles to investigating the immediate type of spontaneous hypersensitivity in man. These have included the lack of in vitro methods of measuring allergic antibody and a limitation on the types of investigations that can be done in man without risk. Models of hypersensitivity using immunized animals have not involved antibody of the type occurring in spontaneous allergy in man. The passive transfer of immediate cutaneous reactivity [Prausnitz-Küstner reaction (1)] to other human subjects has remained the classical method of investigation of allergic antibody. This technique is limited to the study of cutaneous wheal and erythema reactions and carries with it the risk of transmission of certain viral diseases. By this method, allergic antibody has been characterized as a nonprecipitating, heat labile, skin-sensitizing antibody that persists at the injected site for long periods of time (2). The nature of the serum fraction containing allergic antibody, believed to be a $\gamma_{1 \mathrm{~A}}$ type of immunoglobulin by several investigators (3), has been the subject of controversy in regard to either electrophoretic migration or sedimentation characteristics as demonstrated by ultracentrifugal analysis.

The availability of an animal model with the immediate type of spontaneous hypersensitivity as found in dogs with spontaneous pollen hyper-

\footnotetext{
* Submitted for publication July 13, 1964 ; accepted September 24, 1964.

Supported by U. S. Public Health Service research grant AI-04199 from the National Institute of Allergy and Infectious Diseases.

† Career Development awardee, U. S. Public Health Service no. 5-K3-AI-19,460-02.

¥Career Development awardee, U. S. Public Health Service no. GMK3-244-CS. Present address: Department of Pathology, School of Medicine, University of California, Los Angeles.
}

sensitivity has provided a means of investigation of the immunopathology resulting from the interaction of allergic antibody and antigen. With this model, the hypersensitivity has been transferred to normal dogs (4) and the canine allergic antibody characterized and compared with human allergic antibody (5).

The immediate type of spontaneous hypersensitivity, a common clinical occurrence, is most frequently directed against materials that are mixtures of poorly characterized antigens such as pollen or animal epithelial proteins. The occurrence of immediate wheal and erythema type of hypersensitivity in certain patients to animal proteins that are available in relatively pure form has provided a means of studying single antigen-allergic antibody systems $(6,7)$.

It has been reported that allergic antibody (reagin, skin-sensitizing antibody, atopic antibody) from man will sensitize the skin of other primates (8). This transfer of cutaneous reactivity to a heterologous species has recently been directed toward the investigation of cutaneous reactions of various antigens and their respective skin-sensitizing antibodies in monkeys $(9,10)$.

Based on the previous observation of passive cutaneous sensitization of monkeys by local injection of human allergic sera, the present studies extend these observations to demonstrate passive systemic sensitization by human allergic antibody. The antigen-allergic antibody reaction in the passively sensitized primate recipients with resultant release of histamine, local or generalized increase in vascular permeability, and smooth muscle reaction is correlated with symptoms of bronchospasm, conjunctivitis, or anaphylaxis. Microscopic abnormalities of lung and myocardium are recorded that result from the hypersensitive response. The study provides comparative observa- 
tions between immediate hypersensitivity reactions as a result of antigen-allergic antibody combination in dogs and primates.

\section{Methods}

Primate recipients. Four Macaca irus, three Macaca mulatta (rhesus), and one Cercopithecus aethiops (African green) monkey were used in these experiments. All of these had been shown (10) to be suitable cutaneous recipients for human reaginic serum. All monkeys appeared in good general health and had negative reactions to tuberculoprotein skin testing.

Serum donors. Serum was obtained from two patients with ragweed pollinosis and one patient with anaphylactic sensitivity to horse serum. Characteristics of serum donors are shown in Table I. Included for comparison are the results obtained with canine reaginic serum from a dog with ragweed pollinosis (4).

Antigens. Ragweed pollen antigen was prepared by standard techniques (11) and expressed as weight of pollen extracted per volume of final extract. Horse serum albumin (HSA) and horse gamma globulin (HGG) were obtained commercially. ${ }^{1}$ Nitrogen $(\mathrm{N})$ determinations were done by the Markham modification of the micro-Kjeldahl method (2).

Passive cutaneous reactions. One-tenth $\mathrm{ml}$ of various sera was injected intracutaneously. Forty-eight hours later the monkeys received $4 \mathrm{ml}$ of $0.5 \%$ Evans blue dye intravenously followed in 15 minutes by intracutaneous injection of $0.05 \mathrm{ml}$ of $0.1 \%$ pollen antigens or HSA or HGG containing $50 \mu \mathrm{g} \mathrm{N}$ per $\mathrm{ml}$. Sites were examined in 30 minutes, and positive reactions were characterized by edema and cutaneous blueing (Figure 1).

Systemic sensitization of monkeys. Monkeys were sensitized by intravenous injection of reaginic sera in divided doses of 25 or $40 \mathrm{ml}$ per $\mathrm{kg}$ body weight. The injections were given at daily intervals, and animals were challenged 48 hours after the last injection. Anaphylactic challenge consisted of intravenous injection of $2 \mathrm{ml}$ of $3 \%$ ragweed antigen or $2 \mathrm{ml}$ containing $5 \mathrm{mg} \mathrm{HSA}$ $\mathrm{N}$ preceded by intravenous injection of $4 \mathrm{ml}$ of $0.5 \%$ Evans blue dye. The volume and concentration of ragweed antigen chosen for intravenous anaphylactic challenge were based on the amount of antigen resulting in canine anaphylaxis in dogs passively sensitized with canine antiragweed antiserum. The amount of HSA chosen for challenge was arbitrarily selected as an amount that would presumably be in excess of that required to produce anaphylaxis. That quantities of both antigens were in excess was demonstrated by loss of reactivity to local cutaneous testing in those passively sensitized monkeys surviving anaphylaxis.

Aerosol exposure of animals. After total body sensitization by human allergic serum, unanesthetized monkeys were placed in an Isolator chamber and aerosolized with $3 \%$ ragweed delivered by a no. 40 DeVilbiss nebulizer in a manner previously described for similar experiments

1 Pentex Corp., Kankakee, Ill. using dogs (4). Changes in respiratory rate and character were recorded graphically by a pneumograph and recording kymograph in the unanesthetized, restrained monkeys. One monkey (monkey D, Table II) received $4 \mathrm{ml}$ of $0.5 \%$ Evans blue dye and $10 \mathrm{mg}$ of pentobarbital per $\mathrm{kg}$ body weight, after sensitization with 100 $\mathrm{ml}$ of human serum. During exposure to ragweed antigen in the aerosolization chamber, pneumograph recordings were made. After sacrifice by injection of excess pentobarbital, the trachea and bronchi were dissected. A control monkey was treated in similar fashion with the exception of passive sensitization by human allergic serum.

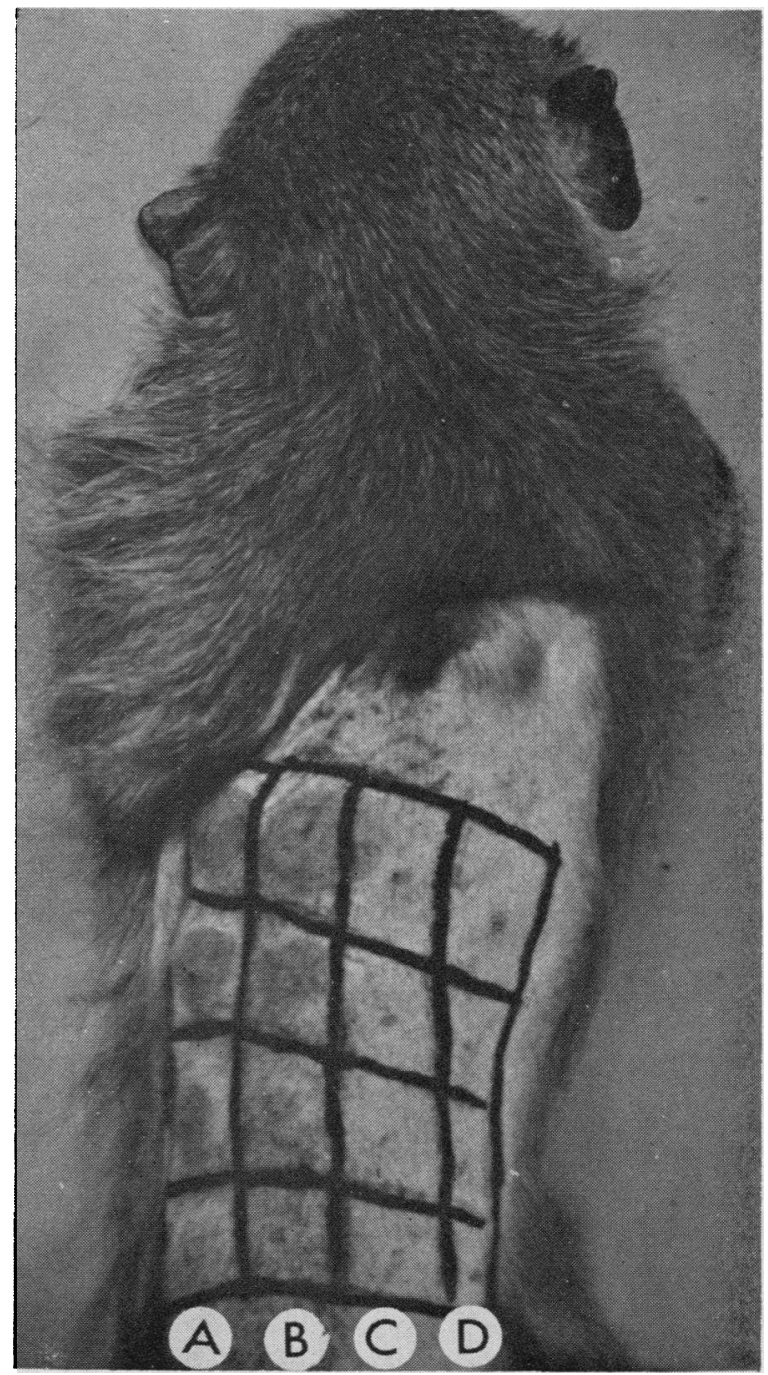

Fig. 1. Monkey Passively Sensitized by LOCAL INJECTIONS OF SERIAL FIVEFOLD DILUTIONS OF HUMAN OR DOG. ALLERGIC SERUM. A) Human antiragweed serum (Donor 1), B) human antihorse serum albumin (Donor 3 ), C) heated serum (Donor 1), D) canine antiragweed serum (Donor 4). See Table I. Sites in A and B and first dilution of $\mathrm{D}$ are positive. 
TABLE I

Some characteristics of donors of serum and the serum used for passive sensitization of monkeys

\begin{tabular}{|c|c|c|c|c|}
\hline Donor & Clinical history & $\begin{array}{l}\text { Cutaneous reactivity } \\
\text { of donor }\end{array}$ & $\begin{array}{l}\text { Passive trans- } \\
\text { fer* to human } \\
\text { skin }\end{array}$ & $\begin{array}{c}\text { Passive } \\
\text { transfer* } \\
\text { to monkey } \\
\text { skin }\end{array}$ \\
\hline 1 & $\begin{array}{l}\text { Ragweed pollinosis with sea- } \\
\text { sonal rhinitis and asthma }\end{array}$ & Ragweed ++++ & $1: 1,250$ & $1: 125$ \\
\hline 2 & $\begin{array}{l}\text { Ragweed pollinosis with sea- } \\
\text { sonal rhinitis and asthma }\end{array}$ & Ragweed ++++ & $1: 1,250$ & $1: 25$ \\
\hline \multirow[t]{2}{*}{3} & \multirow{2}{*}{$\begin{array}{l}\text { Rhinitis and asthma after ex- } \\
\text { posure to horses and dogs; } \\
\text { systemic reaction of asthma, } \\
\text { urticaria, and hypotension } \\
\text { after accidental contact of } \\
\text { horse serum with conjunctiva }\end{array}$} & $\begin{array}{l}\text { Horse serum albumin, } \dagger \\
0.08 \mu \mathrm{g} \mathrm{N} / \mathrm{ml}\end{array}$ & $1: 1,250$ & $1: 125$ \\
\hline & & $\begin{array}{l}\text { Horse gamma globulin, } \dagger \\
1.2 \mu \mathrm{g} \mathrm{N} / \mathrm{ml}\end{array}$ & $1: 10$ & 0 \\
\hline 4 & $\begin{array}{l}\text { Dog with spontaneous ragweed } \\
\text { pollinosis with dermatitis, } \\
\text { rhinitis, and asthma (see } \\
\text { reference 4) }\end{array}$ & Ragweed & Positive & $1: 5$ \\
\hline
\end{tabular}

* Recorded as highest serum dilution giving positive titer.

$\dagger$ Recorded as minimal amount of antigen giving positive reaction on direct cutaneous testing.

$\ddagger$ Titer in human skin not done. Positive in transfer to dog skin to a dilution of $1: 125$.

Blood histamine determinations. Blood histamine levels were determined by the method of Shore, Burkhalter, and Cohn (12). During anaphylactic shock histamine levels were determined on blood samples obtained by cardiac puncture.

Post-mortem examinations were done within $30 \mathrm{~min}$ utes of spontaneous death or sacrifice of monkeys.

\section{Results}

\section{Local cutaneous reactivity}

Examples of cutaneous reactivity transferred by intracutaneous injections of human sera are shown in Figure 1. Columns $\mathrm{A}$ and $\mathrm{B}$ demonstrate reactions at transfer sites and the method of titering passive transfer reactions. Column C shows the destruction of reaginic antibody by heating reaginic serum to $56^{\circ} \mathrm{C}$ for 4 hours before passive transfer experiments. In this monkey even undiluted canine antiragweed serum gave only a weakly positive reaction (column $\mathrm{D}$ ), but in other experiments the same canine allergic serum was positive to a dilution of $1: 5$. Table I records certain characteristics of serum donors and their allergic antisera. The comparative ability of the human or canine allergic antisera to transfer reactivity to homologous or heterologous skin is demonstrated by the highest dilution of the antisera that can still successfully transfer cutaneous reactivity. Transfer of the cutaneous reactivity to the heterologous recipient was less suc- cessful with either the human or canine allergic antisera. Whether this difference in ability to sensitize heterologous skin is a result of variation in response of monkey skin to the antigen-antibody reaction, inability of human and canine reagin to fix to skin of monkeys to the same degree as in human skin, or other explanation, is uncertain.

\section{Systemic sensitization of monkeys by reaginic serum}

Monkeys receiving a sufficient amount of reaginic serum intravenously developed systemic sensitization that could be demonstrated by several methods.

A) Local cutaneous reactions. The monkeys sensitized with antiragweed or anti-HSA reagin developed systemic sensitivity demonstrated by wheal and erythema type reactions after intracutaneous challenge with either antigen.

$B$ ) Mucosal reactivity. Objectives of this portion of the investigation were to demonstrate that immediate type sensitivity in conjunctival or respiratory mucosa occurs after passive sensitization by intravenous administration of sufficient amounts of reaginic antiserum.

1) Conjunctival reactivity. After intravenous administration of $4 \mathrm{ml}$ of $0.5 \%$ Evans blue dye, 2 drops of $3 \%$ ragweed antigen placed in one conjunctival sac of animals passively sensitized with human antiragweed serum resulted in intense 


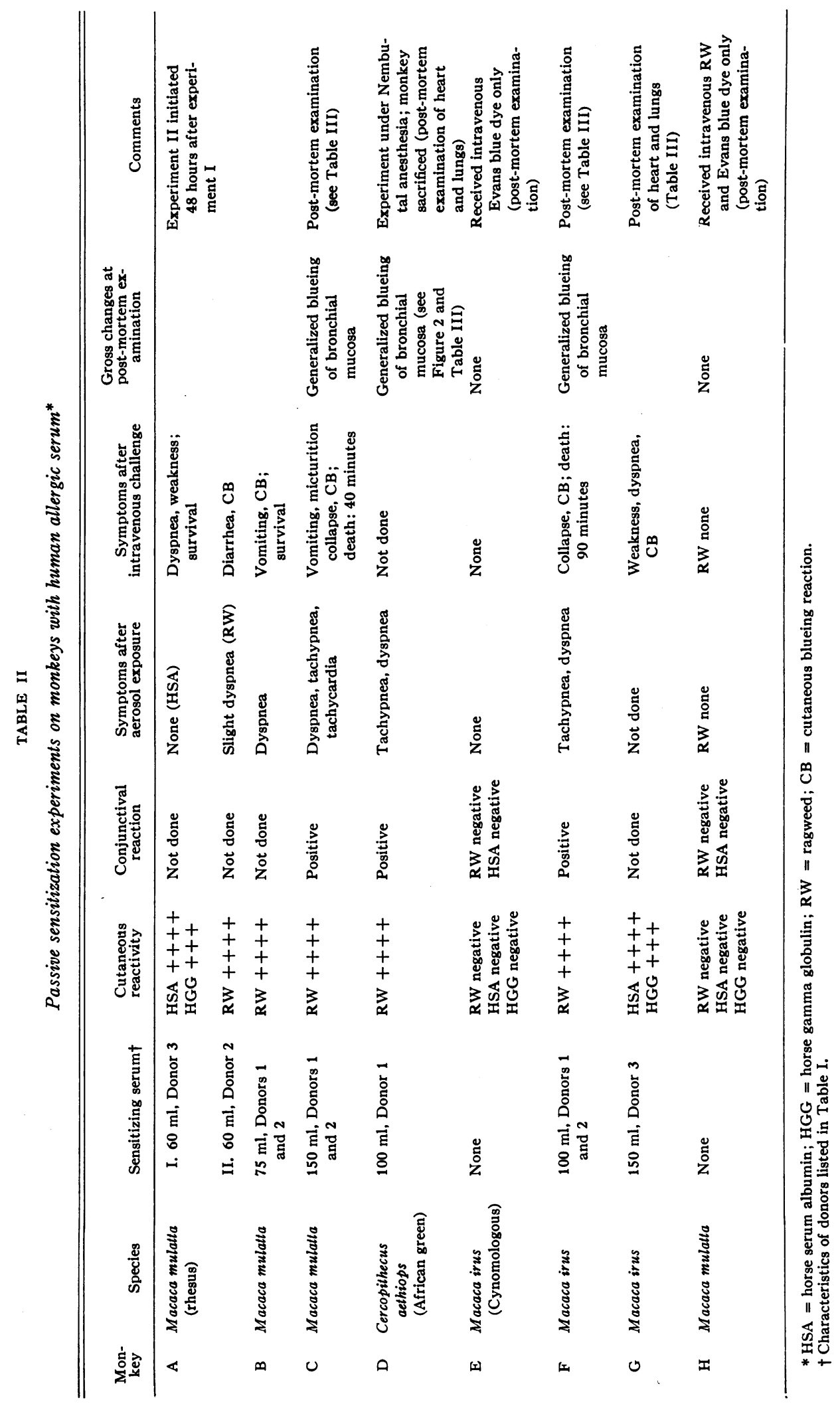


blueing reaction of the tested conjunctiva. The control conjunctival sac tested with an extraneous antigen appeared unchanged after 30 minutes.

2) Bronchial reactivity. Monkeys sensitized by intravenous antiragweed serum received $4 \mathrm{ml}$ of $0.5 \%$ Evans blue dye and were exposed by aerosol to $3 \%$ ragweed antigen in a closed environment. Clinical manifestations consisted of increased respiratory rate, prolonged expiratory phase, and intermittent grunting respirations. Flaring of the nasal alae during the acute phase occurred in all animals. Expiratory wheezes at termination of the experiment were present in some monkeys. Exposure of normal monkeys under similar conditions resulted in no symptoms. Dissection of bronchi from a passively sensitized monkey exposed to ragweed under the above circumstances demonstrated a blueing reaction of the bronchial mucosa. The appearance of the bronchial mucosa is similar to the appearance of the reactive skin sites in passive cutaneous anaphylaxis, and it is likely that these changes represent extravasation of dye due to an antigen-antibody reaction in the bronchial mucosa similar to that occurring in the skin sites in a passive cutaneous anaphylactic reaction. The clinical alterations occurring as a result of aerosol exposure to ragweed antigen can be observed by graphic recordings with a pneumograph. The recordings demonstrated that tachypnea and some change in the character of respirations occur after exposure to aerosolized ragweed antigen. This model of induced respiratory distress should provide a valuable system for study of acute physiologic alterations. The respiratory changes as a result of the passive sensitization and aerosol exposure to antigen may, therefore, be studied by clinical observation, graphic recording of thoracic respiratory movements, and acute changes in the appearance of bronchial mucosa demonstrated by the blueing reaction.

C) Anaphylaxis. Monkeys systemically sensitized by the administration of human allergic serum developed anaphylactic shock as a result of intravenous challenge with specific antigen ( $\mathrm{Ta}$ ble II). Manifestations of anaphylaxis included diarrhea, vomiting, collapse, dyspnea, and death. All of these symptoms were not present in each shocked animal. A striking change occurred in some animals receiving Evans blue dye before anaphylactic challenge. Associated with the occurrence of clinical manifestations in some monkeys, there was a generalized cutaneous blueing indicating an increase in capillary permeability in the skin. Other monkeys in anaphylaxis developed irregular areas of local cutaneous edema with an appearance similar to urticaria, and a more marked localized blueing of these areas was present than occurred in generalized blueing. The generalized cutaneous reaction appeared to be associated with more severe anaphylaxis than the localized urticarial type.

The blood histamine concentration of the normal monkey was in the range of $0.07 \mu \mathrm{g}$ histamine per $\mathrm{ml}$. (Normal dog blood histamine in this laboratory ranges from 0.03 to $0.09 \mu \mathrm{g}$ of histamine per $\mathrm{ml}$ ). During the period of anaphylactic shock, blood histamine ranged from $0.29 \mu \mathrm{g}$ histamine per $\mathrm{ml}$ (monkey A, Table II) to $0.53 \mu \mathrm{g}$ histamine per $\mathrm{ml}$ (monkey $\mathrm{C}$, Table II). Thus, approximately a four- to eightfold increase in blood histamine concentration occurred during anaphylaxis. Lee-White clotting times (13) showed no change during the period of anaphylaxis in contrast to the infinite clotting times observed during acute canine passive anaphylaxis (4).

Post-mortem abnormalities in monkeys after anaphylactic shock were observed only in the heart and lungs. Microscopic examination of liver, kidneys, spleen, and large and small intestines of monkeys $\mathrm{C}$ and $\mathrm{F}$ were done and showed no definite abnormalities. Microscopic examination of lungs from monkeys C, D, F, and G showed acute emphysema. Thus, acute emphysema occurred whether there was an intravenous challenge alone (monkey $\mathrm{G}$ ), aerosol challenge alone (monkey D), or both (monkeys C and F). Abnormalities were observed in the hearts of all monkeys following anaphylaxis. The microscopic changes observed in these hearts are recorded in Table III. Figure 2 depicts an example of a myocardial lesion with a focal infiltrate of lymphocytes and neutrophiles. Although the pericardial adipose tissue shows some inflammatory reaction, the myocardium constitutes the primary site of the exudative reaction. Arteritis, focal necrosis, and inflammatory cells in the myocardium of monkey D were present although challenged only by aerosol exposure to antigen. However, the concentration of aerosolized ragweed antigen used in these 
TABLE III

Summary of pathological findings in myocardium of monkeys after passive sensitization and aerosol or intravenous challenge

\begin{tabular}{|c|c|c|c|c|c|}
\hline Monkey* & Vessels & Hyperemia & Hemorrhage & Necrosis & $\begin{array}{l}\text { Inflammatory } \\
\text { cells }\end{array}$ \\
\hline $\mathrm{C}$ & Moderate arteritis & $4+$ & $4+$ focal & $\begin{array}{l}3+ \\
\text { Moderately } \\
\text { diffuse }\end{array}$ & $\begin{array}{ll}\mathrm{M} \dagger & 2+ \\
\mathrm{N} & 2+\end{array}$ \\
\hline $\mathrm{D}$ & Slight arteritis & None & None & $4+$ focal & $\begin{array}{ll}\mathrm{M} & 3+ \\
\mathrm{N} & 4+\end{array}$ \\
\hline$\stackrel{\mathrm{E}}{\text { (Control) }}$ & None & None & None & None & None \\
\hline F & Focal arteritis & None & None & None & None \\
\hline G & Endarteritis & $3+$ & $2+$ focal & $2+$ focal & $\begin{array}{ll}\mathrm{M} & 2+ \\
\mathrm{N} & 2+\end{array}$ \\
\hline$\underset{\text { (Control) }}{\mathrm{H}}$ & None & None & None & None & None \\
\hline
\end{tabular}

* See Table II.

$\dagger \mathbf{M}=$ monocytic cells.

$\ddagger N=$ neutrophilic granulocytes.

experiments was in great excess of that which would be encountered in environmental exposure.

\section{Loss of capacity to accept sensitization}

One month after the experiment recorded in Table II, monkeys A and B, which had previously been passively sensitized by intravenous injection of 120 or $75 \mathrm{ml}$ of human allergic sera, respectively, were injected with human sera, this time locally with $0.1 \mathrm{ml}$ of sera from Donors 1 , 2 , and 3 and these sites tested for the presence of immediate type sensitivity to ragweed, HSA, or HGG. Reactions were negative, indicating the loss of ability to accept skin sensitivity as a result of prior injection of human serum. The initial injections of human sera that resulted in passive sensitization of the monkeys had also actively sensitized the monkeys. Thus, after a latent period, the injection of additional human reaginic serum failed to sensitize the monkey skin. Sera collected from monkeys A and B were tested for the presence of precipitating antibody against human serum, human gamma globulin, and human serum albumin by ring precipitin and Ouchterlony type double gel diffusion precipitin reactions (2). No precipitating antibody was detected by these tests, but the sera of monkeys $A$ and $B$ demonstrated the presence of circulating antibody against human serum protein antigens by sensitization of normal monkey skin for passive cutaneous anaphylactic reactions against human se- rum. In addition, monkeys $\mathrm{A}$ and $\mathrm{B}$ demonstrated symptoms of anaphylaxis accompanied by the generalized cutaneous blueing reaction when challenged intravenously with $2 \mathrm{ml}$ of human serum. This reaction never occurred in monkeys at the time of the first injection of human serum.

\section{Discussion}

Methods of studying allergic antibody include the passive transfer of cutaneous reactivity in man

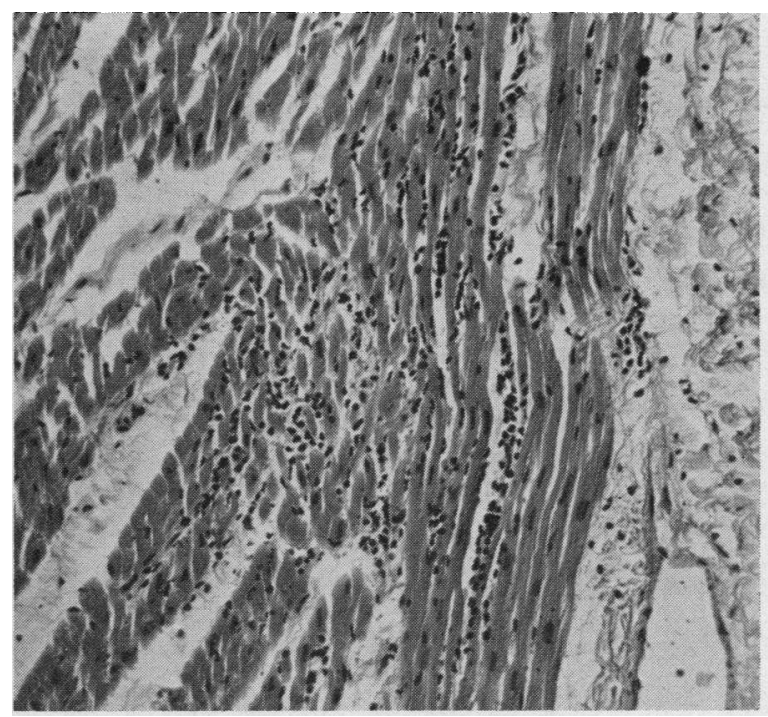

Fig. 2. A SECTION OF EPICARDIAL FAT AND MYOCARDIUM SHOWING A FOCAL INFILTRATE OF LYMPHOCYTES AND NEUTROPHILES. The primary site of the inflammatory reaction is in the myocardium. $\times 80$. 
and the transfer of cutaneous and total sensitivity in dogs. These models provide a means of comparative study of this antibody. The transfer of local cutaneous and total body sensitivity by human allergic serum to monkeys provides a third major model for the study of allergic antibody.

The events presumed to occur in a passive cutaneous reaction after sensitization with allergic antibody in man include the attachment of allergic antibody to skin cells, reaction of injected antigen with antibody, the release of chemical mediators from cells, and resultant increase in capillary permeability. The latter is demonstrated by the characteristic wheal reaction and made more visible by extravasation of Evans blue dye. The passive cutaneous anaphylactic reaction of Ovary (2) is a similar reaction as a result of induced, skin-fixing animal antibody. The allergic antibody occurring in man will attach to normal human leukocytes in vitro by passive sensitization as detected by histamine release determination (14).

Canine allergic antibody from dogs with ragweed pollinosis, asthma, and dermatitis will passively transfer cutaneous, bronchial mucosal, and anaphylactic sensitivity (4). Histamine levels and pathologic changes during anaphylaxis in dogs passively sensitized with this canine reaginic serum can thus be compared with induced anaphylaxis in the dog in which the antibody has not yet been defined. This model of the immediate type of hypersensitivity provides a useful comparison between the immediate type of hypersensitivity of two species, man and dog.

Human allergic antibody has the following immunologic characteristics: it is a nonprecipitating antibody, which is heat labile at $56^{\circ} \mathrm{C}$, fixes to skin, and persists at the skin site (3). Canine allergic antibody has identical characteristics in completed studies using presently developed immunologic techniques (5). Although in vitro methods of detecting antibody in human allergic sera have evolved (15), it has not been established that these in vitro techniques actually measure allergic antibody.

As demonstrated in the experiments described, the injection of sufficient amounts of human allergic serum into monkeys results in total body sensitization. The monkey that has been totally sensitized in this manner can react to antigenic challenge with the specific antigen-human antibody reaction in a manner similar to the sensitive human. The use of the monkey for this type of sensitization is obligatory, since no other nonhuman species has been found to accept the transfer of human allergic antibody. Skin-sensitizing activity of canine antisera will transfer to man and monkey, but human allergic antisera will not transfer to dog, guinea pig, or rabbit.

The availability of the monkey sensitized with human serum provides several potentially useful areas of investigation. The cutaneous reaction has been used as a method of antigen evaluation $(9,10)$ and study of fractions of allergic antisera (16). The use of Evans blue dye as an indicator in these reactions provides an indication of wheal and erythema reactivity, making a reaction more visible for graphic recording. The extravasation of Evans blue dye at the site of cutaneous reaction is an indication of the increased capillary permeability as a result of the antigen-antibody reaction and release of mediators. This occurs in a local mucosal reaction demonstrated in these experiments in which antigen was placed in contact with the conjunctival mucosa. Blueing of the bronchial mucosa occurs in those monkeys with systemic sensitivity after exposure to specific antigen in aerosol form with subsequent development of symptoms of respiratory distress. Finally, during systemic anaphylactic shock in the passively sensitized monkey injected with Evans blue dye before antigenic challenge, a cutaneous blueing reaction is consistently observed. This varies in different animals from a generalized blueing to circumscribed areas of cutaneous blueing with an appearance not dissimilar from that of acute urticarial reactions, as may be seen in anaphylaxis in man. The generalized blueing suggests the occurrence of an increase in cutaneous capillary permeability as the result of the systemic reaction.

The events and mechanisms resulting in anaphylactic shock in the passively sensitized monkey appear to be consistent with the following pathophysiologic pattern. After intravenous injection of human allergic serum, reaginic antibody results in systemic sensitization with fixation of the antibody to cells demonstrated by the general cutaneous and bronchial reactivity to antigen. After intravenous challenge, the antigen-allergic antibody interaction results in histamine release demonstrated by increase in blood histamine levels. The 
subsequent increase in vascular permeability demonstrated by generalized cutaneous blueing is followed by clinical symptoms of shock. The concomitant occurrence of smooth muscle spasm is shown by symptoms of vomiting, micturition, and diarrhea in varying degree, and the pulmonary symptoms and pathologic demonstration of pulmonary emphysema may represent acute changes resulting from the smooth muscle spasm in the bronchi. The variations in type or severity of symptoms and variation in severity of pathologic changes represent biologic differences between experimental subjects. The occurrence of the pathologic changes of acute emphysema in some of the monkeys examined after anaphylactic shock represents pulmonary abnormalities that may have contributed to the systemic symptoms of anaphylaxis. Since the symptoms of anaphylactic shock do not occur in passively sensitized monkeys challenged by aerosol alone, it appears reasonable to consider the anaphylactic shock primarily the result of the intravenous challenge, with pulmonary manifestations a secondary phenomenon.

The pathologic abnormalities in the monkeys after passive anaphylaxis represent changes resulting from the specific conditions of method of passive sensitization, challenge, duration of anaphylaxis, and whether death occurs spontaneously. The acute emphysema demonstrated in these monkeys after anaphylaxis is an abnormality not unexpected in view of the respiratory symptoms occurring during shock and similar observations in some humans (17) and some dogs (4) after spontaneous or experimental anaphylaxis. The myocardial abnormalities observed in all sensitized monkeys exposed to the respective antigen are striking in terms of consistency and character. These changes appear to represent primary changes as the result of the antigen-allergic antibody interaction. Similar myocardial changes have not been described in man (17). Such myocardial abnormalities may represent specific species localization of pathologic changes in the monkey in anaphylaxis [comparable to the liver, gall bladder, and intestinal tract abnormalities in the $\operatorname{dog}(4,5)]$, or similar abnormalities may be found when larger series of post-mortem studies of human anaphylaxis are available. Further investigation of the myocardial abnormalities described in these experiments is in progress. Studies to correlate the myocardial abnormalities with severity and duration of anaphylactic shock are required.

The duration of passively transferred systemic sensitivity will depend on the antibody content of the sensitizing serum, amount of serum given, and the half-life of human reaginic antibody (which has not yet been determined) in the monkey. Finally the duration of the passive sensitivity in the monkey depends on the development of monkey antibody against the sensitizing serum and immune elimination of the sensitizing antibody from the monkey. The present experiments indicate that monkeys receiving amounts of serum used in these studies cannot be used for sensitization after 1 month; two monkeys developed sensitivity to the human sera used for passive immunization.

The antibody developed by the monkeys against human serum was demonstrated only by active anaphylaxis or passive cutaneous anaphylaxis and not by precipitation reactions. Monkeys immunized with human serum in Freund's adjuvant develop precipitating antibodies (18). The difference between these immunologic responses of monkeys is probably dependent upon the adjuvant administered with the antigenic serum.

\section{Summary}

Total antibody sensitization of monkeys occurs with sufficient passively transferred human allergic serum. Cutaneous, respiratory, and anaphylactic reactions can be studied with this model of human hypersensitivity. The symptoms, blood histamine levels, and pathologic changes in the passively sensitized monkey can be compared with a similar type of reaction in the dog. Microscopic pathologic changes occurring in anaphylaxis in monkeys sensitized by human allergic sera were acute pulmonary emphysema and arteritis, focal necrosis, and focal hemorrhages in the myocardium.

\section{References}

1. Prausnitz, C., and H. Küstner. Studien über die Ueberempfindlichkeit. Zbl. Bakt. I. Abt. Orig. 1921, 86, 160.

2. Kabat, E. A., and M. M. Mayer. Experimental Immunochemistry. Springfield, Ill., Charles C Thomas, 1961.

3. Stanworth, R. A. Reaginic antibodies in Advances in Immunology, F. J. Dixon, Jr., and J. H. Humphrey, Eds. New York and London, Academic Press, 1963, vol 3. 
4. Patterson, R., and D. B. Sparks. The passive transfer to normal dogs of skin reactivity, asthma and anaphylaxis from a dog with spontaneous ragweed pollen hypersensitivity. J. Immunol. 1962, 88, 262.

5. Patterson, R., J. J. Pruzansky, and W. W. Y. Chang. Spontaneous canine hypersensitivity to ragweed. Characterization of the serum factor transferring skin, bronchial and anaphylactic sensitivity. J. Immunol. 1963, 90, 35.

6. Patterson, R., J. J. Pruzansky, and S. M. Feinberg. Studies on reactions of human allergic serum with serum protein antigens. I. Methods of passive immune elimination and gel diffusion autoradiography. J. Allergy 1962, 33, 236.

7. Pruzansky, J. J., R. Patterson, and S. M. Feinberg. Studies on reactions of human allergic serum with serum protein antigens. II. Method of quantitative demonstration by a coprecipitation technique. J. Allergy 1962, 33, 381.

8. Straus, H. W. Studies in experimental hypersensitiveness in the rhesus monkey. II. Passive local cutaneous sensitization with human reaginic sera. J. Immunol. 1937, 32, 251.

9. Layton, L. L., and E. Yamanaka. Demonstration of human reagins to foods, cat dander, an insect, and ragweed and grass pollens. J. Allergy 1962, 33, 271.
10. Layton, L. L., W. E. Greer, F. C. Greene, and E. Yamanaka. Passive transfer of human atopic allergies to catarrhine and platyrrhine primates of suborder anthropoidea. Int. Arch. Allergy 1963, 23, 176.

11. Hepler, O. E. Manual of Clinical Laboratory Methods. Springfield, Ill., Charles C Thomas, 1949.

12. Shore, P. A., A. Burkhalter, and V. A. Cohn, Jr. A method for the fluorometric assay of histamine in tissues. J. Pharmacol. exp. Ther. 1959, 127, 182.

13. Todd, J. C., and A. H. Sanford. Clinical Diagnosis by Laboratory Methods. Philadelphia and London, W. B. Saunders, 1948.

14. VanArsdel, P. P., Jr., and C. J. Sells. Antigenic histamine release from passively sensitized human leukocytes. Science 1963, 141, 1190.

15. Pruzansky, J. J., and R. Patterson. Binding of $I^{131}$-labeled ragweed antigen by sera of ragweedsensitive individuals. J. Allergy 1964, 35, 1 .

16. Buckley, R. H., and R. H. Metzgar. The use of nonhuman primates for studies of reagin. Fed. Proc. 1964, 23, 402.

17. James, L. P., and K. F. Austen. Fatal systemic anaphylaxis in man. New Engl. J. Med. 1964, 270, 597.

18. Lichter, E. A., and S. Dray. Immunoelectrophoretic characterization of human serum proteins with primate antisera. J. Immunol. 1964, 92, 91. 